\title{
Rising Farm Exports and International Trade Policies
}

\author{
CLIFTON B. LUTTRELL.
}

E XPORTS of farm commodities in 1978 totaled $\$ 29.4$ billion, almost 27 percent of the value of all cash farm receipts, and a further increase in farm exports is expected this year. Farm exports have increased rapidly and consistently during the past decade both in nominal value and as a percent of cash farm receipts. The nominal value of such exports last year was more than five times that of 1969 and such exports, as a percent of cash farm receipts, more than doubled over the period. Despite this sharp increase, however, farm exports as a percent of cash farm receipts have only recently regained the levels that existed in the early 1920s.

This article suggests that much of the increase in those of the 1920s and early 1930s, many farm groups have supported such restrictive policies in the past and continue to support them today.

\section{MAPN ENPORTS ASSOCATLD WITH TOTAL MMORTS}

Farm exports tend to move in the same direction as total exports, and both tend to move in the same direction as total imports. Chart 1 shows that, aside from World War II and the immediate post-war years when foreign aid was a major portion of total exports, exports and imports as a percent of GNP generally have moved in the same direction. Chart 2 shows the same general movements for exports of the proportion of farm products exported in recent years is a result of major changes in U.S. and other nations' foreign trade policies. The restrictive trade legislation of the 1920 s and 1930s sharply reduced imports which, coupled with retaliatory restrictions imposed by other nations, also reduced U.S. exports. This reduction hurt the farm sector severely (see box). This article further demonstrates that despite the damage to farmers caused by restrictive trade policies such as

The inpact of rising demand for U.S. farm exports on the price and production of US farm products is demonstrated in the following diagram, $\mathrm{S}=$ supply curve for US fam products $D_{1}$ - demand curve of domestic consumers for such products, D. domestic plus expont denand for US, fam products, and $D_{2}, D_{1}=$ expont demand. The price and production of farm produets willout exports is $\mathrm{P}$ and $Q$, respectively, With exports and higher overall denand $(\mathrm{D}$, , price and production of fam products 15 ${ }$, and $Q$, respectively, and any hrorease in forelgn denand will increase total demand $\left(\mathrm{D}_{2}\right.$ ), and price and production.

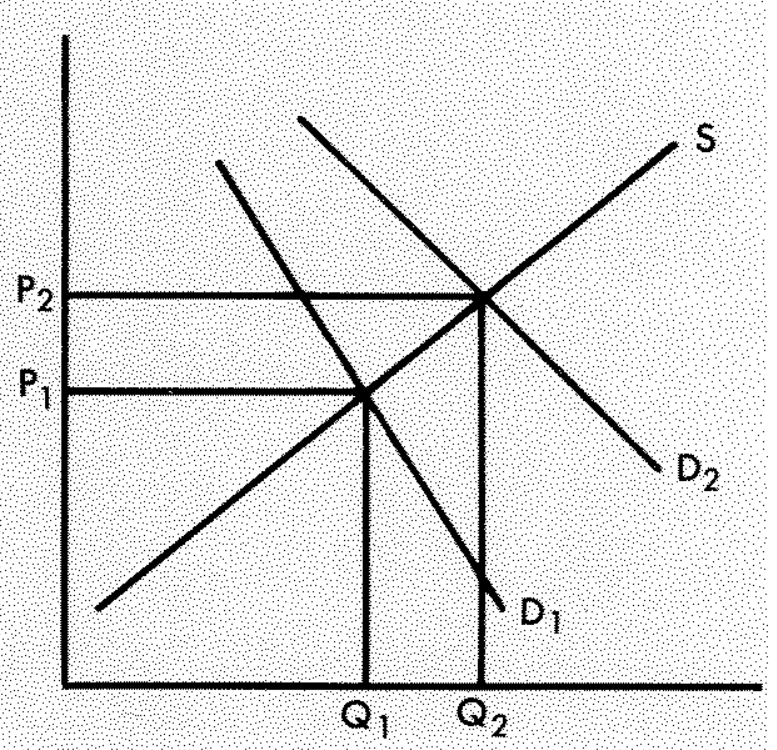




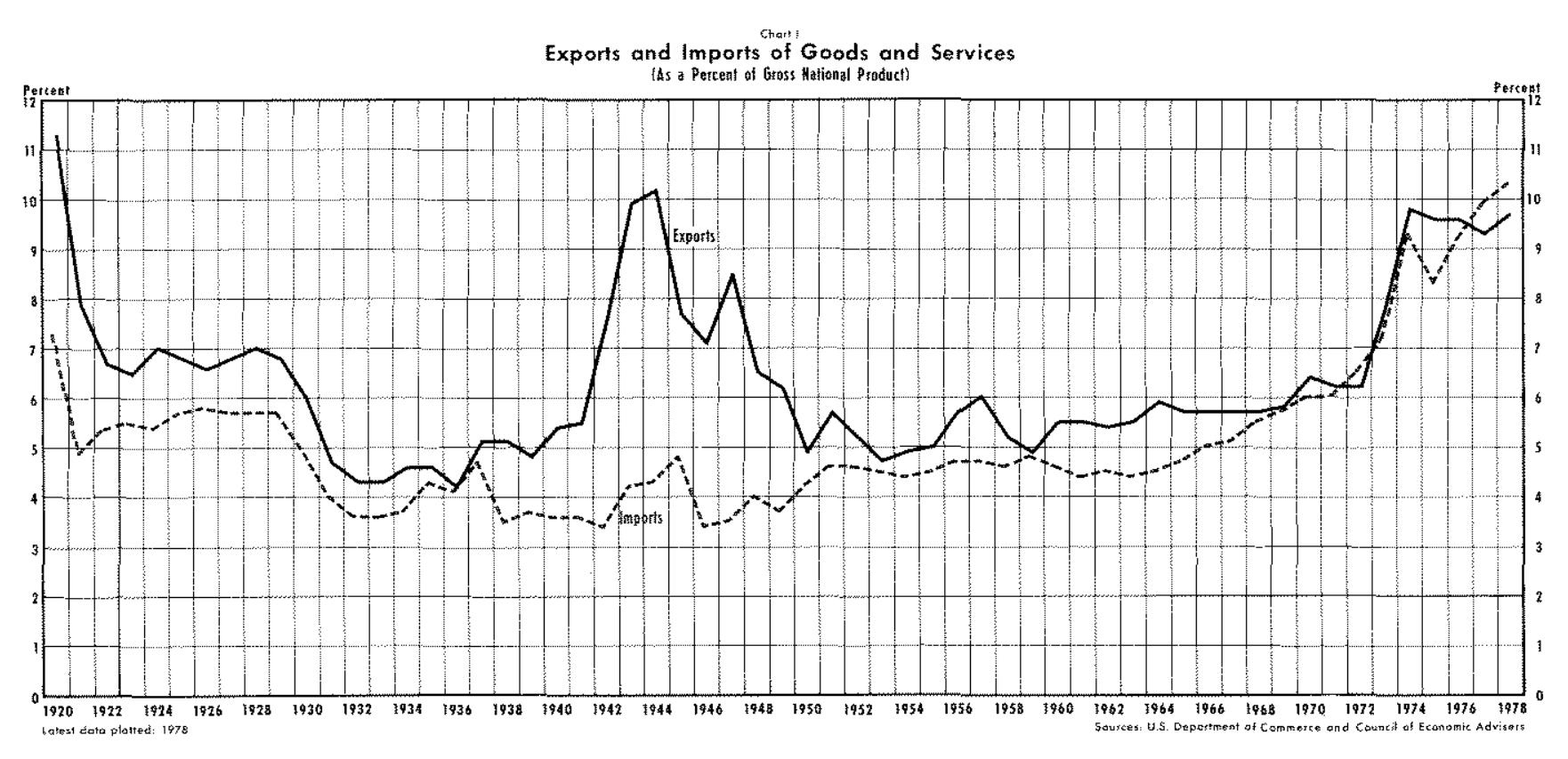

farm products as a percent of cash farm receipts. Statistical analysis confirms these relationships; the changes in imports and exports are highly positively correlated as are the changes in farm exports and total imports. ${ }^{1}$

Given constant levels of real income in the trading nations, two factors tend to produce similar movements in exports and imports of goods and services. First, tariff changes by one nation usually are reciprocated by other nations. For example, following the enactment of the Smoot-Hawley Tariff Act of 1930 , higher U.S. duties on imports were quickly followed by higher import duties in Canada, Cuba, Mexico, France, Italy, Spain, Australia, and New Zealand. The following year India, Peru, Argentina, Brazil, and China also levied higher duties. ${ }^{2}$

Second, under a flexible exchange rate system, movements in the exchange rate tend to balance

1The annual change in exports of goods and services over the period $1901-78$, excluding the years of $1939-50$, is positively correlated with the change in imports; the correlation coeffcient is .88 . Over periods longer than a year, the correlation of changes in imports and exports is even higher. Using twoyear averages, the correlation coefficient is .93 and with fiveyear averages, the correlation is .99 . Similarly, the annual change in farm exports is positively correlated with the change in total imports; the correlation coefficient is .69. Using twoyear and five-year averages, the correlation coefficients are .77 and .93 , respectively.

2P. T. Ellsworth, The International Economy (New York: The Macmillan Company, 1950), p. 501, and Allan H. Meltzer, "Moretary and Other Explanations of the Start of the Great Depression," Journal of Monetary Economics (November $1976)$, p. 460 . trade over an extended period of time even without reciprocity of tariff rate changes. The exchange rate - the value of the dollar in terms of other currencies - like the price of any other good, is determined by the supply and demand for dollars. Over a period of time, changes in the supply of dollars in foreign exchange markets reflect the value of U.S. imports plus U.S. investments abroad. When such imports and investments rise relative to U.S. exports plus foreign investments in the United States, the supply of dollars in foreign exchange markets increases relative to the demand for dollars and the exchange value of the dollar falls. Conversely, when exports of U.S. commodities and foreign investments in the United States rise, the quantity of dollars supplied to foreign exchange markets decreases and the exchange value of the dollar in these markets rises.

These fluctuations in the value of the dollar tend to equate the dollar value of U.S. exports and imports through the domestic currency prices of internationally traded goods. ${ }^{3}$ For example, if the value of the dollar

\footnotetext{
3 In contrast to the current method in which trade plus net investment flows are balanced between nations, under the gold and gold exchange standards, the flows were balanced through gold specie or gold bullion transfers. During those periods in which the stock of money in a nation was influenced by the quantity of gold held, the flow of specie or bullion out of a nation in payment for excess imports led to a reduction in domestic prices relative to world prices and thereby to a reversal in trade and the balance of payments. During much of the gold exchange standard period following 1933, revisions in the exchange rates were made by govemments in response to unequal rates of inflation in the various nations. Such revisions often served to reverse imbalances in trade.
} 


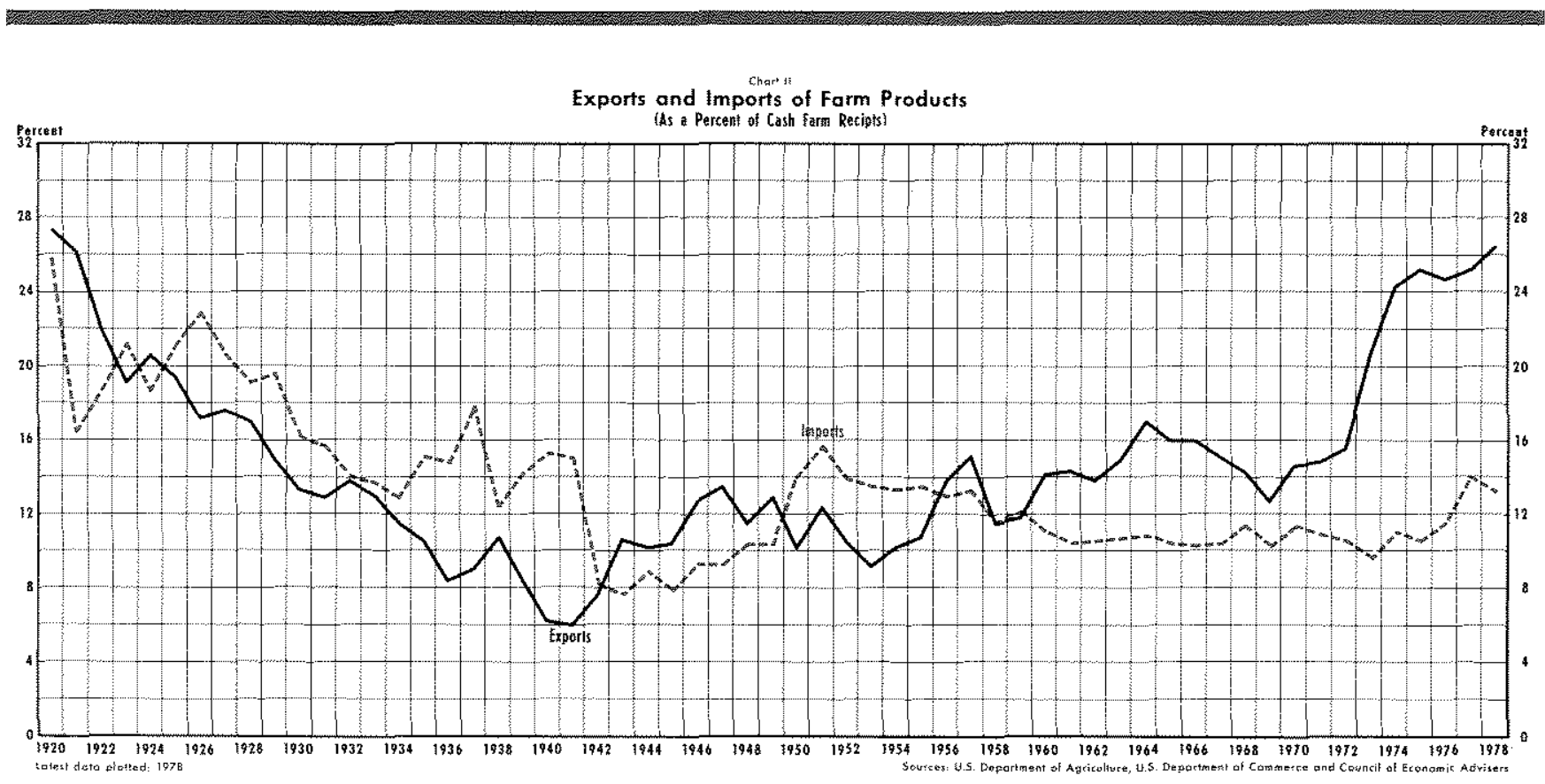

falls relative to the value of the Japanese yen, prices of Japanese television sets to U.S. consumers will rise; consequently, fewer Japanese television sets will be purchased. But the Japanese, finding that U.S. wheat and soybeans can be purchased for fewer yen, will import more of these products. Similarly, if the value of the U.S. dollar falls relative to all foreign currencies, foreign residents will find U.S. goods cheaper than before, and U.S. exports will increase. Conversely, if the value of the dollar rises relative to other currencies, U.S. citizens will find that the dollar prices of foreign goods have fallen relative to U.S. goods, and imports will increase. ${ }^{4}$ Given the tendency for the exchange rate mechanism to equate the dollar value of exports and imports, attempts to reduce imports will have a similar effect on the demand for exports including exports of farm products.

\section{RESTRTTIV MPORT POLICTES LED TO DECWNES IN TOTAL MPORTS, PARM FXPONTS, AND FARM PNCOMT}

As shown in Chart 2, exports as a percent of cash farm receipts declined throughout most of the twenties

\footnotetext{
4 While Kravis and Lipsey found sizable differences in the dollar prices of foreign traded goods in various countries for an extended period of time, exports rose at the highest rate in those nations where prices were lowest. I. B. Kravis and $\mathrm{K}$. E. Lipsey, "Price Behavior in the Light of Balance of Payment
}

and thirties from an average of 25.2 percent in 1920 22 , to 13.4 percent in $1930-32$, to 8.4 percent in 1938 40. This decline in exports followed the adoption of more restrictive trade policies by the United States and other countries. The sharp decline in farm commodity prices in 1921, which followed the domestic business recession and the European agricultural recovery from World War I, prompted Congress to attempt to "protect" farmers with an emergency tariff on farm products. The duties on wheat, corn, meat, wool and sugar were raised. In 1922 the FordneyMcCumber Tariff Bill was enacted, raising the average ad valorem (percent of value) rates on dutiable imports to about 40 percent - back to the levels of 1913. Duties were increased on numerous farm products including wheat, corn, beef, eggs, reindeer meat, peanuts, beet and cane sugar, wool, and acorns. Additional "concessions" to farmers were the removal of duties on agricultural implements such as plows, harrows, reapers, cotton gins, etc. The Smoot-Hawley Tariff Act of 1930, initiated as another measure for "pro" tecting" agriculture from foreign competition, raised import duties to the highest levels in the nation's his-

Theories," Journal of International Economics (May 1978), p. 230 . Henry Goldstein found that relative domestic price levels have a substartial and significant impact on the exchange rate. See "Floating Exchange Rates and Modified Pur" chasing Power Parity: Evidence from Recent Experience Using an Index of Effective Exchange Rates" published in West Coast Academic/Federal Reserve Economic Research, Federal Reserve Bank of San Francisco, 1978, p. 174. 


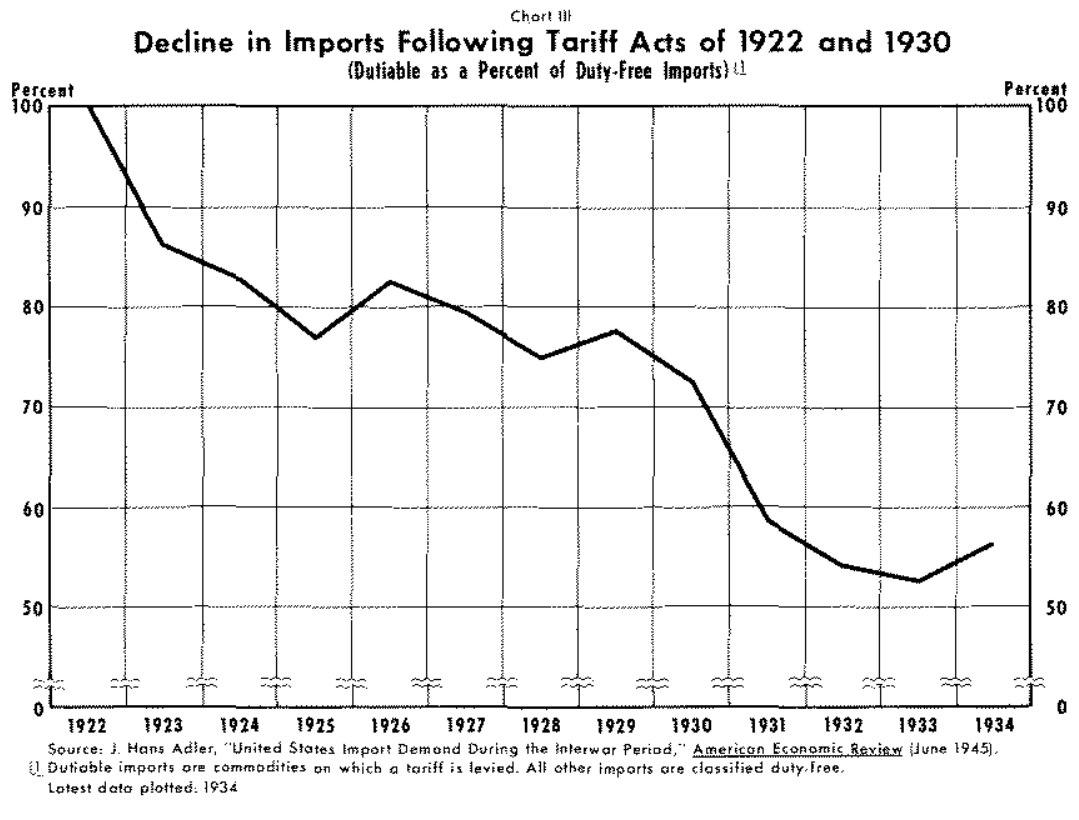

tory. Although already high by historical standards, rates were further increased on more than 800 items,

The initial 1921 emergency tariff had little effect on the volume of foreign trade or on farm commodity exports. The United States was a net exporter of most of the commodities being protected and remained so. Hence, the protective features of the act were largely illusory. The Fordney-McCumber Tariff Act in 1922 and the Smoot-Hawley Act in 1930, however, significantly reduced import growth, thereby setting in motion forces that reduced exports of farm products.

Imports as a percent of GNP declined from 7.3 percent in 1920 to about 5.4 percent in 1922. They remained near that level until 1930 when they declined even further as a result of the Smoot-Hawley Tariff and the Great Depression. They dropped to 3.6 percent of GNP in 1932 and remained near this level throughout the remainder of the decade (Chart 1). Total exports followed the same general pattern. Exports of farm products, however, declined faster than exports of nonfarm products as farmers in other nations

$\mathrm{s}_{\mathrm{F}}$ W. Taussig, The Tariff History of the United States (New York: Augustus M. Kelley, 1967), pp, 452, 455, 504-11. Rates were increased on numerous farm products including sugar, cotton, cattle, beef, sheep, mutton, swine, com, milk, cream, eggs, live ponltry, hides, leather, onions, tomatoes, cabbages, turnips, and blueberries. demanded and generally received greater protection than the nonfarm sector. Farm exports declined from 22 percent of cash farm receipts in 1922 to 8.4 percent in 1936.

One statistical study of U.S. demand for imports found evidence that the tariffs were a major factor in the decline of imports during the 1920s and early 1930s. The study demonstrated that the tariffs caused a greater reduction in dutiable imports (imports on which tariffs were levied) than in duty-free imports. After eliminating the effects of shifts in imports from duty-free to dutiable, and vice versa, the study found that dutiable imports as a percent of duty-free imports declined sharply following the higher duties in both 1922 and 1930 (Chart 3). During the three years following the 1922 Act, the index of the quantity of dutiable imports declined to 77 percent of the index of duty-free imports, and in the three years following the 1930 Act, the index of dutiable imports declined further to 53 percent of the duty-free imports. ${ }^{6}$ Since exports are closely associated with imports, the tariffs were indirectly a major factor in the decline of farm exports.

Since exports accounted for such a large portion of U.S. farm commodity sales ( 15 percent in 1929), the decline in farm exports had a greater impact on farm income than the decline in nonfarm exports had on income in the nonfarm sector. Hence, farm incomes declined more dramatically than did nonfarm income. For example, farm income declined at an average annual rate of 31 percent during the $1929-32$ period, compared with a 17 percent rate for total personal income.

If the tariff accounted for the difference between the percentage decline in total personal income and farm income during the period, about 40 percent of the decline in farm income during 1929.32 can be attributed to it. If farm income had declined only at the rate of the national aggregates, net farm income in 1932 would have totaled about $\$ 3.6$ billion instead of $\$ 2.0$ billion.

6. Hans Adler, "United States Import Demand During the Interwar Period," American Economic Review (fume 1945), pp. 418-30. 


\section{PISNG WAMM EXPORTS AND INCOMES FOLUOWED FPEER TPADE POLICIES}

Much of the increase in farm exports since the mid-1950s can be attributed to a gradual reduction in foreign trade restrictions. ${ }^{7}$ Beginning with the Reciprocal Trade Agreements Act of 1934, a series of tariff-reducing acts and negotiations have led to major reductions in international trade barriers. Initially, these bilateral reductions achieved only limited success since duties on most dutiable imports were well above the minimum levels that provided incentives for trade.

Since the war and the General Agreement on Tariffs and Trade (GATT) in 1947, a number of major reductions in average ad valorem rates have been negotiated. The permissible reductions and average duties on dutiable imports are listed in Tables I and $\mathrm{IL}$.

Studies indicate that these reductions have had a major impact on U.S. imports. Kreinin analyzed the effect of the tariff reductions granted in the 1955 negotiations (which resulted in a 28 percent reduction in the 1954 rates on the covered group of commodities) and found that the volume of imports of commodities on which tariffs were reduced rose 59 percent, whereas imports of the nonreduced group rose only 17 percent. Similarly, following the 1956 negotiations (which resulted in a 15 percent reduction in rates for the affected group), imports of the reduced group increased 12 percentage points more than the nonreduced group. ${ }^{8}$

A study by Stern, based on the import demand for 226 commodity groups, concluded that total imports in 1960 would have been $\$ 4.1$ billion (about 25 percent) more than the actual level had no tariffs or quotas existed. ${ }^{9}$ A study in 1965 by Balassa found

\footnotetext{
TDomestic price support programs and crop production controls, which caused the prices of some products to rise above free market levels, were factors that tended to reduce exports of some crops, especially wheat, cotton, and tobacco. These supports and controls, however, had little impact on the prices of such major export crops as feed grain and soybeans, indicating that the removal of trade restrictions was a major factor in the rise in exports of these products. U.S. Government holdings of feed grain and soybeans through price support operations did not exceed 15 percent and 30 percent of production, respectively, at the close of any year follow ing 1963. Furthermore, the holdings of both were almost as large in the recent years of rising exports as in the early $1960 \mathrm{~s}$.

sMordechai E. Kreinin, "Effect of Tariff Changes on the Value and Volume of Imports," American Economic Review (June 1961), pp. 314-16.

9Robert M. Stern, "The U.S. Tariff and the Efficiency of the U.S. Economy," American Economic Review (May 1964),
} p. 464 .
Toble

Tarif Cuis Authorized by the Vorious Trade Acts

Trode Agreements Acts

Act 011934

401,1945

Act of 1955

Act of 1058

Act of 1962

Act of 1974

Maximum Pernis sible Redoction

50 percent of July 1,1034 rate

50 percent of anuan 1,1945 rate

15 percent of lanuary 1,1955 rate

20 percent of July, 1,1958 rite

50 percent of 9 uly 1,1962 rote

60 , percent of existing rete

SOURCE, United States Thiff Commission.

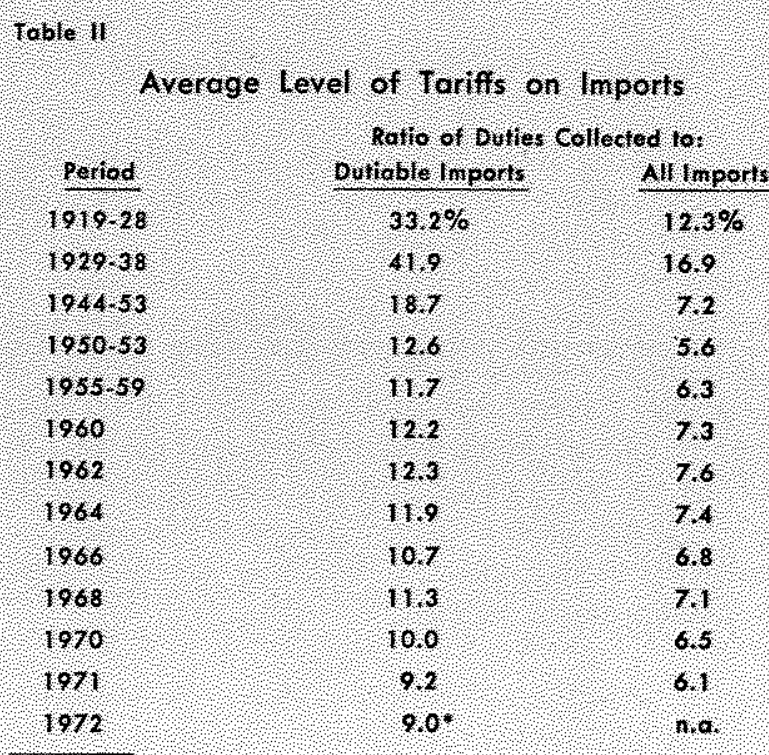

$\rightarrow$ exdides petroledra.

Soureb, United states Tarif Commisston.

that effective duties (the degree of protection for the manufacturing process) in the United States were generally higher than nominal rates, and with potentially higher supply elasticities in the United States than in other industrial countries, imports would rise faster here with the elimination of tariff duties. $\mathrm{He}$ concluded that, if such elasticities are 50 percent higher here than elsewhere, imports would rise by 54 percent with the elimination of duties. ${ }^{10}$

Reductions in tariff duties do not effectively increase trade immediately. The effect of such actions lag, and in some cases the reductions do not result in any change in trade. Many of the rates in the mid-

10Bela Balassa, "Tariff Protection in Industrial Countries," Journal of Political Economy (December 1965), p. 593. 


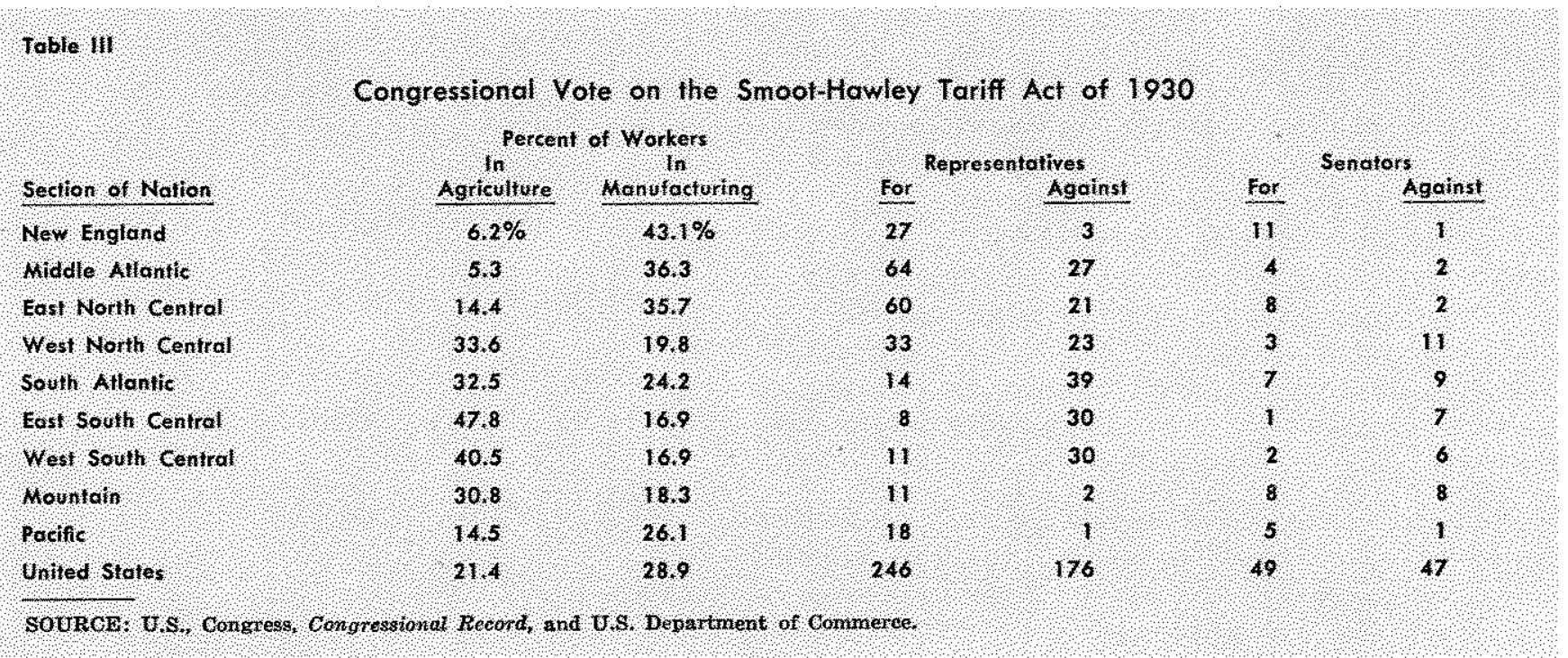

1950s were well above the minimum prohibitive trade level (the tariff level at which no trade will occur) and the reductions only reduced the excess protection. Furthermore, as lower rates provided incentives for trade, foreign producers still needed time to arrange for merchandising and distributing facilities in the United States. Exporters of goods to the United States had been effectively shut out of the U.S. market for about 25 years - in the 1930s because of the SmootHawley Tariff, in the 1940s because of the war, and in the early 1950 s because of the time required to prepare for increased exports. ${ }^{11}$

By the mid-1950s, U.S. tariff rates on a large number of commodities had been reduced to a level which provided incentives for trade, and several international organizations were established to increase exports to the United States. Imports of goods and services as a percent of GNP increased moderately in the early $1960 \mathrm{~s}$ from 4.5 percent to 6 percent in 1970 and to 10 percent in 1978 (Chart 1). By 1978, imports as a percent of GNP were the largest for any year since the turn of the century.

Total exports and farm commodity exports followed the pattern of total imports. As a percent of GNP and of farm cash receipts, respectively, they started up in the $1950 \mathrm{~s}$, continued moderately up through the $1960 \mathrm{~s}$, and rose at a sharply higher rate in the 1970s. Exports of farm products rose from about 10 percent of cash receipts in the early $1950 \mathrm{~s}$, to about

\footnotetext{
${ }^{11}$ Kreinin, "Effect of Tariff Changes," p. 319; also William P. Travis in "Production, Trade and Protection When There Are Many Commodities and Two Factors," American Economic Review (March 1972), pp. 100-02.
}

15 percent in the $1960 \mathrm{~s}$, to about 25 percent since the mid-1970s.

The sharp increase in farm exports had a favorable effect on farm income. Gross farm income rose at an 8.4 percent rate from 1969 to 1978 , about the same rate as GNP growth. In contrast, during the previous 10 years when farm exports were rising more slowly, gross farm income rose only 4.0 percent per year compared with a 6.8 percent rate of GNP growth.

\section{THE FARM SECTOR HAS NOT CONSISTENTLY OPPOSED RESTRCTIE TRADE POLICIES}

Despite the fact that protective tariffs have generally harmed the well-being of farmers, elected representatives from major farming states have in some cases supported highly protective tariff legislation. Such support apparently was obtained by imposing duties on imports of farm products that would not have been imported even without tariffs and exempting farm implement imports from tariffs even though none were imported anyway. The Secretary of Agriculture's report to the President in late 1930 pointed out these "favorable" aspects of the Smoot-Hawley Tariff Act. He showed that the schedule for farm products was increased an average of 69 percent, whereas all schedules were increased an average of only 20 percent. He argued that a protective tariff must become a more integral part of our national agricultural policy. ${ }^{2}$ Such arguments apparently gained support for the Act.

12U.S. Department of Agriculture, Yearbook of Agriculture 1931 (Government Printing Office, 1931), p. 42-44. 
The voting record in Congress indicates that sizable support for this highly protectionist measure came from some of the leading farm states. The House of Representatives opposed the act in only three of the nine major sections of the nation, and the Senate opposed it in only four. The vote in the Senate, however, was close (Table III). Support for the act was strongest in New England and the Middle Atlantic states, where the percentage of workers in agriculture was relatively small and the percentage in manufacturing relatively large. The proportion of workers in agriculture averaged 6.2 and 5.3 percent, respectively, in the two regions. On the other hand, a majority of representatives supported the act in such agricultural areas as the West North Central and Mountain states, and large majorities supported it in both the House and Senate in the Pacific states.

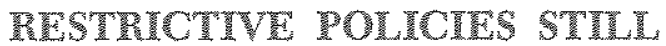 RECEYV NUCH FA}

Despite the major shrinkage both in the market for U.S. farm products and in farm income resulting from the ill-advised tariff of 1930, and despite the expansion of exports following the reduced tariffs in the $1950 \mathrm{~s}$ and 1960 s, recent actions of farm groups are not unequivocally opposed to protectionist policies. Evidence indicates that farmers still are sensitive to possible increases in agricultural imports. Organized and highly articulate groups of farmers, while largely interested in the protection of specific farm products, still support foreign trade policies which would result in high tariffs for farm products in general.

Sugar cane and sugar beet producers, for example, still insist on legislation to maintain domestic prices above world prices and to protect growers from "lowprice" foreign sugar. ${ }^{13}$ The National Livestock Feeders Association has gone on record against the "ivory tower" free trade philosophy that has characterized U.S. trade policy for the past several years. The executive vice president of the association, in hearings before the Senate Committee on Finance in 1974, argued that our free trade policy has brought irreparable harm to U.S. agriculture and industry and opposed proposed legislation to "wipe out" any duty of not more than 5 percent ad valorem, since this would permit the free entry of a number of meat products. ${ }^{14}$ Despite his contention that the U.S. dairy

\footnotetext{
13See John Valentine, "President's Sugar Price-Support Plan Welcomed as End to a Key Uncertainty," The Wall Street Journal, February $21,1979$.

14U.S., Congress, Senate, Committee on Finance, The Trade Reform Act of 1973, 93rd Cong,, 2nd sess., March 25, 1974,
} pp. 947-64. industry is, as a whole, among the most efficient industries in the world, the secretary of the National Milk Producers Federation argued strongly against free trade. He stated in the above hearings: "Despite all the fine sounds of free trade and expanded international cooperation we must first take stock of our own national interests." 15 While reaffirming the $\mathrm{Na}$ tional Farmers Union's traditional position in support of expanding foreign trade, its national secretary in the same hearings opposed any further reduction of tariff and nontariff barriers. He contended that further reductions in trade restrictions would undermine farm prices in both the United States and the European Economic Community. ${ }^{16}$ The American Farm Bureau Federation, although making a strong statement for free trade in general, recommended at the hearings that Title II of the act be amended so that farmers could more readily obtain relief from injury caused by import competition. ${ }^{17}$

The Agricultural Adjustment Act is indicative of the strong support for protection for specific farm products, delegating sufficient authority to limit the imports of almost any product that is competitive with U.S. farm products. The act directs the Secretary of Agriculture to advise the President when he believes that any farm commodity or product is being imported in quantities that will interfere with farm price support or other USDA programs. The President may then direct the International Trade Commission to conduct an investigation, after which he may proclaim new duties or quantitative restrictions on the imports. ${ }^{18}$

The maintenance of such a pattern of protection for farm commodities places this nation in an unfavorable bargaining position for free trade in farm commodities. The United States has just concluded the Tokyo Round of negotiations which will take effect starting in January 1980. In these negotiations, the United States obtained a broad range of tariff and nontariff concessions that are expected to significantly increase agricultural exports over the next decade. Among those products on which trade barriers were reduced are beef, pork, poultry, tobacco, fruit, vegetables, oilseeds, and nuts. ${ }^{19}$ Nevertheless, agricultural trade barriers are perhaps the most diffi-

\footnotetext{
15Ibid., pp. 964-89.

16Ibid, pp. 1030-31.

17 Ibid., p. 1011.

18United States International Trade Commission, "Operation of the Trade Agreements Program," 26th Report, 1974, p. 32 .

${ }_{19}$ U.S. Department of Agriculture, Agricultural Ontlook (May $1979)$, p. 10.
} 
cult of all restrictions to remove. For this reason, a positive view toward free trade in farm products by this nation is highly desirable.

The argument often given in support of farm commodity protection is that this country has lower duties on farm products than most other nations. This argument, however, is meaningless in view of our comparative advantage in production. A more appropriate way of measuring relative duties is to compare this nation's duties on farm products with other nations' duties on products in which they have a comparative advantage. In only a few farm commodities, such as sugar and wool where we do not have a comparative advantage, is such a comparison with other nations meaningful. Significantly, our policies with respect to sugar cannot be considered liberal by either foreign producers or domestic consumers. Apparently the farm sector is willing to accept free trade policies only if "reasonable" restraints are established on imports of competitive products. Such a posture, if all nations maintained it at the bargaining table, would not permit the resource adjustments necessary for trade or for the attainment of the potential gains to U.S. agriculture from exports.

Given the U.S.'s comparative advantage in the production of farm products, most farmers have little to fear from imports. The alleged protection for crops such as wheat, rice, corn, cotton, soybeans, tobacco, and livestock products, where net exports are realized, is actually little protection. Such products are generally more valuable when exported and when the proceeds are exchanged for foreign goods than when sold on the domestic market; hence, these products will not be imported except possibly along the Canadian or Mexican borders which have special transportation advantages.

Protection for other major products that may experience minor competition from imports (such as beef, other processed and frozen meats, and dairy products) could be self-defeating, especially if such regulations trigger retaliatory protective measures abroad. Any loss of foreign markets for the major exported crops, such as cotton, tobacco, wheat, feed grain, soybeans, and rice, will lead to lower domestic prices for such products and eventually will result in a shift of farm resources from these products into the production of tariff-protected products such as beef, other meats, and dairy products. In other words, those sectors which experience minor competition from imports under free trade practices would realize more competition from domestic farmers whose products can no longer be sold in the export market.
Another argument often made for protection is that, given a protected market for industrial goods, we will have more workers employed by nonfarm industries and an expanded domestic market for farm products. ${ }^{20}$ With such policies, however, gains from international specialization of labor and resource use would be lost. In other words, each nation without trade must depend upon its own resources for the production of each good even though it may be relatively inefficient in producing some goods. The total quantity of goods available for consumption will thus be less for both farm and nonfarm sectors without trade than with trade. Consequently, it is inconsistent with the general well-being of the farm sector, as well as the nation at large, for farm groups to pursue protectionist policies.

\section{SUMMARY}

The U.S. farm sector potentially has more to gain from free international trade than virtually any other sector of the economy. Exports of farm products constitute about 30 percent of the market for U.S. farm products. In contrast, exports account for less than 10 percent of the value of manufactured goods. Nevertheless, many farm groups have left a record of confusion with respect to their position on foreign trade policies.

They have failed to recognize the link between imports and exports. Changes in imports are closely associated with changes in total U.S. exports. Consequently, they are closely associated with the level of farm exports given the comparative advantage of the United States in farm production. U.S. imports provide foreigners with income to purchase U.S. farm products. Free trade policies, therefore, tend to directly increase imports and thereby enhance farm commodity exports. In addition, they induce other nations to adopt similar policies which further enhance trade.

20 If domestic price supports and production controls were a major factor in the current levels of farm incomes, it could be argued that farmers are making rational decisions in trading some of their foreign market exports for the short-run gains from domestic price supports. Such supports, however, have been much smaller in recent years relative to farm income, and losses in the export market from protectionist policies would not likely be offset. Only relatively snall sectors of the agricultural industry (largely sugar and tobacco producers) have received major benefits from the price supports and production controls in recent years. Furthermore, prior to 1933, when farm support for protective tariffs was perhaps as great or greater than today, the nation had no farm production controls and no price supports for most farm products. 